\title{
Michał Buszko, Marlena Ciechan-Kujawa
}

Uniwersytet Mikołaja Kopernika w Toruniu

e-mails: mibus@umk.pl;marlenac@umk.pl

\section{RELACJE Z INTERESARIUSZAMI I ICH WYCENA - WYBRANE ASPEKTY}

\section{RELATIONS WITH STAKEHOLDERS}

AND THEIR VALUATION - SELECTED ASPECTS

DOI: $10.15611 /$ pn.2018.531.05

JEL Classification: M11, M31, M41

Streszczenie: Interesariusze stanowią grupy, które bezpośrednio lub pośrednio, uczestniczą w wymianie wartości z przedsiębiorstwem. W wyniku oddziaływania na przedsiębiorstwo, jak i siebie nawzajem tworzą sieć relacji, stanowiących niematerialne zasoby. Relacje z interesariuszami stanowią integralne składowe wartości przedsiębiorstwa i podlegają wycenie. Celem artykułu jest identyfikacja czynników determinujących tworzenie relacji z interesariuszami, określenie podejść oraz wskazanie kluczowych problemów związanych z ich wyceną. Praca ma charakter teoretyczny, a do jej przygotowania wykorzystano studia literatury oraz analizę aktów prawnych. Badania wskazują na wieloaspektowość problemu, wynikającą z faktu zróżnicowania grup interesariuszy i relacji, zmienności ich w czasie, jak również braku korzyści ekonomicznych osiąganych wprost z tytułu relacji z częścią interesariuszy. W przypadku pomiaru i wyceny relacji istotnie ograniczone staje się wykorzystanie metod wyceny przedsiębiorstw.

Slowa kluczowe: interesariusze, relacje z interesariuszami, wycena.

Summary: Stakeholders are groups that directly or indirectly participate in the exchange of values with an enterprise. As a result of their impact on the enterprise, as well as to each other, they form a network of relations constituting intangible resources. Relations with stakeholders are integral components of the company's value and are subject to valuation. The aim of the paper is to identify determinants of creation of relations with stakeholders, to identify approaches and key problems related to their valuation. The work is of a theoretical nature and its preparation has been based on literature studies and analysis of legal acts. Research indicates the multifaceted nature of the problem resulting from a diversity of stakeholders and relations, their changes in time, as well as a lack of economic benefits achieved directly from the relations with some stakeholders. In the case of measuing and pricing of relation, the use of enterprise valuation methods becomes strongly limited.

Keywords: stakeholders, relations with stakeholders, valuation. 


\section{Wstęp}

Interesariusze i relacje z nimi stanowią współcześnie obszar determinujący działalność właściwie każdego podmiotu gospodarczego. Współistnienie oraz wzajemna interakcja w ramach jednego podmiotu potrzeb, oczekiwań oraz wpływów różnych grup interesu należących zarówno do jego wnętrza, jak i do szeroko rozumianego otoczenia społeczno-gospodarczego, powoduje konieczność poświęcania temu zagadnieniu coraz większej uwagi oraz rozwoju zarządzania relacjami z interesariuszami. Choć w naukach ekonomicznych kategoria interesariuszy pojawiła się już w latach 30. XX wieku, na bazie wzrostu oczekiwań społecznych w odniesieniu do wielkich korporacji, to sama teoria interesariuszy została rozwinięta i kompleksowo zdefiniowana oraz spopularyzowana dopiero przez R.E. Freemana [Freeman, Reed 1983; Freeman 1984] w latach 80. Teoria ta wykraczała poza tradycyjnie postrzegane relacje $z$ otoczeniem gospodarczym, koncentrując się na identyfikacji podmiotów, które jako grupa lub osoba mogą mieć wpływ na funkcjonowanie organizacji i osiąganie przez nią celów. Uwzględniając długookresową perspektywę działania organizacji oraz wymiar strategiczny podejmowanych decyzji, Freeman wskazywał na konieczność rozszerzenia tradycyjnego pojęcia interesariuszy, obejmującego: akcjonariuszy, klientów, dostawców, o inne grupy interesów: pracowników, kredytodawców, media, społeczeństwo, władze i instytucje rządowe i samorządowe. Spojrzenie przez ten pryzmat było fundamentem opracowania metod zarządzania interesariuszami oraz ich relacjami z przedsiębiorstwem.

Współcześnie w literaturze przedmiotu można spotkać się z opinią, iż to właśnie umiejętność nawiązywania przez organizacje relacji z wybranymi partnerami otoczenia staje się źródłem strategicznych sukcesów rynkowych i źródłem przewag konkurencyjnych, poprzez uzyskiwanie wartości dzięki tworzeniu, łączeniu i wymianie zasobów [Lechner i in. 2006; Skalik 2006; Adamik 2009]. Relacje tworzone przez przedsiębiorstwo z różnymi grupami interesu powinny być tym samym traktowane jako rodzaj kapitału, zwanego relacyjnym lub też intelektualnym.

Podstawowym problemem związanym z procesem tworzenia i zarządzania relacjami jest pomiar i ocena efektywności poszczególnych relacji, w tym w szczególności ich wycena na potrzeby zarządcze przedsiębiorstwa.

Celem artykułu jest identyfikacja kluczowych czynników wpływających na tworzenie i rozwój relacji z interesariuszami, zaproponowanie podejść do wyceny tych relacji z punktu widzenia przedsiębiorstwa, a także wskazanie głównych problemów związanych z tą wyceną. W opracowaniu autorzy skoncentrują się zwłaszcza na charakterystyce interesariuszy, procesie tworzenia relacji z nimi, a także traktowania relacji jako rodzaju aktywów niematerialnych, podlegających wycenie. Praca jest oparta przede wszystkim na bazie studiów literatury i ma charakter teoretyczny. Stanowi ona podstawę do dalszych badań w zakresie uwarunkowań, doboru oraz zastosowania praktycznego metod wyceny relacji z interesariuszami. 


\section{Interesariusze $\mathbf{i}$ ich znaczenie $\mathbf{w}$ działalności przedsiębiorstwa}

Opisywane w literaturze przedmiotu kluczowe klasyfikacje interesariuszy odnoszą się do ich miejsca w strukturze jednostki [Dundee 2008, s. 346-358], typu powiązań z jednostką [Esty, Winston 2007, s. 65-68; Freeman i in. 2007, s. 8-9; Hawkins 2006, s. 142-150; Lawrence, Weber 2008, s. 7-11], postawy [Johnson, Scholes 1999, s. 216] oraz charakteru zależności. Do interesariuszy zaliczane są podmioty, które w sposób bezpośredni lub pośredni oraz pieniężny lub niepieniężny uczestniczą w wymianie wartości z przedsiębiorstwem poprzez dostarczanie zasobów lub korzystanie z nich. Jednocześnie podmioty te, jak podkreśla Obłój [2014, s. 44], są w stanie wywrzeć efektywną presję na przedsiębiorstwo. Pozostają one zatem w przymusowym bądź dobrowolnym związku z nim, ponosząc pewne ryzyko, ale także - jak wskazuje Romanowska [2004, s. 151] - wpływają na poziom ryzyka samego przedsiębiorstwa.

$\mathrm{Z}$ punktu widzenia niniejszego artykułu istotne jest miejsce interesariusza w strukturze jednostki. W tym ujęciu wskazać należy na interesariuszy wewnętrznych oraz interesariuszy zewnętrznych, do których należą jednostki pozostające w bezpośrednim związku biznesowym oraz jednostki bez bezpośredniego związku biznesowego. W zależności od branży, otoczenia i rozmiaru podmiotu, grupy kluczowych interesariuszy mogą różnić się między sobą.

Od czasów sformułowania teorii interesariuszy przez R.E. Freemana podejście do roli interesariuszy w działalności gospodarczej uległo istotnym zmianom. Andriof i Waddock [2002, s. 20-23, 31] upatrują tych zmian w wielopłaszczyznowości i interaktywności współczesnych relacji interesariuszy z organizacją. Wskazują, że wymusza to na przedsiębiorstwach konieczność budowy modeli biznesowych zorientowanych relacyjnie i procesowo. Ciechan-Kujawa [2014, s. 27-28] zwraca dodatkowo uwagę, że zdolność przedsiębiorstwa do rozwoju jest tak naprawdę zależna od zdolności do zbudowania spirali kreowania wartości w relacjach z interesariuszami i wykorzystania efektu działania tej spirali do tworzenia wartości przedsiębiorstwa. Kompleksowa analiza przepływu wartości powinna być prowadzona w dwóch kierunkach: jednostka-interesariusze i interesariusze-jednostka. Jest to istotne, ponieważ, jak podkreślają Morsing [2006, s. 325] oraz Freeman, Harisson i Wics [2007, s. 3-4], rzeczywisty wzrost poziomu zaangażowania interesariuszy w długoterminowe tworzenie wartości wymaga zarządzania nie tyle interesariuszami, ile jakością i dynamiką wzajemnych relacji. Należy zwrócić przy tym uwagę, że miejsce wartości w relacjach z interesariuszami przesuwa się ze sfery kontraktów i transakcji dobrowolnych do sfery zaufania i współpracy. Jak zauważa Laszlo [2008, s. 15], to dynamika interakcji i jakość relacji z klientami, pracownikami, dostawcami, inwestorami i innymi interesariuszami coraz częściej determinują możliwość rozwoju jednostki i tworzenie przez nią wartości. 


\section{Relacje $\mathrm{z}$ interesariuszami - rodzaje i czynniki kreacji}

Wpływ interesariuszy na przedsiębiorstwo zależy od celu podejmowanej współpracy [Wit, Meyer 2007, s. 221-223], sposobu powiązania poszczególnych grup z przedsiębiorstwem [Niedzielski 2005, s. 59], charakteru relacji [Czakon 2008, s. 7-8], płaszczyzny oddziaływania na organizację [Lawrence, Weber 2008, s. 12] i stopnia wpływu na nią [Mitchell i in. 1997, s. 853]. Opis kluczowych relacji przedstawiono w tabeli 1. Trwałość konkretnego związku i kierunek zależności wynikają z okoliczności wystąpienia danej relacji oraz celów, które chcą osiągnąć obie strony.

Tabela 1. Czynniki kształtujące relacje z interesariuszami

\begin{tabular}{|c|c|}
\hline Kryterium & Rodzaj relacji \\
\hline $\begin{array}{l}\text { Cel podejmowanej } \\
\text { współpracy }\end{array}$ & $\begin{array}{l}\text { - relacje nastawione na dzielenie się zasobami, } \\
\text { - na integrację działań, } \\
\text { - na zgranie pozycji (wspieranie, lobbing) }\end{array}$ \\
\hline $\begin{array}{l}\text { Sposób powiązania poszcze- } \\
\text { gólnych grup z przedsiębior- } \\
\text { stwem }\end{array}$ & $\begin{array}{l}\text { - kontraktowe - opierające się na formalnie ustalonych zasadach } \\
\text { współpracy (np. relacje z pracownikami, bankami, indywidualny- } \\
\text { mi inwestorami), } \\
\text { - quasi-kontraktowe - opierające się na ogólnie obowiązujących } \\
\text { przepisach (np. relacje z klientami, instytucjami samorządowymi), } \\
\text { - niekontraktowe - występujące w niesformalizowanej postaci, czę- } \\
\text { sto nieuświadomione do momentu pojawienia się problemu (np. re- } \\
\text { lacje z grupami konsumenckimi, grupami ekologicznymi) }\end{array}$ \\
\hline Charakter relacji & $\begin{array}{l}\text { - konkurencyjny (relacje antagonistyczne), } \\
\text { - operacyjny (relacje hierarchiczne - oparte na strukturach i syste- } \\
\text { mach kontroli, relacje rynkowe - oparte na kontraktach formal- } \\
\text { nych, zabezpieczeniach dwustronnych, relacje społeczne - oparte } \\
\text { na zaufaniu, normach społecznych, wymianie informacji) }\end{array}$ \\
\hline Płaszczyzna oddziaływania & $\begin{array}{l}\text { - głos w podejmowaniu decyzji - akcjonariusze, } \\
\text { - wpływ ekonomiczny - wynikający ze stopnia uzależnienia od po- } \\
\text { szczególnych grup interesariuszy, tj. klientów, dostawców i hur- } \\
\text { towników, ciągłości działania, poziomu wyników finansowych, } \\
\text { - wpływ polityczny - wynikający bezpośrednio z regulacji rzą- } \\
\text { dowych i ustawodawstwa oraz lobbingu innych grup interesów } \\
\text { na rzecz zmian prawnych, } \\
\text { - wpływ prawny - oddziaływanie na biznes w przypadku nadużyć } \\
\text { i zniszczeń spowodowanych przez przedsiębiorstwo zarówno kon- } \\
\text { sumentów, pracowników, jak i działaczy społecznych }\end{array}$ \\
\hline $\begin{array}{l}\text { Stopień wpływu na organi- } \\
\text { zację }\end{array}$ & $\begin{array}{l}\text { - władza - zdolność wpływania na organizację, } \\
\text { - legitymizacja - prawne, zwyczajowe lub moralne prawo uzasadnia- } \\
\text { jące związki z organizacją, definiujące prawa, ale również ryzyka } \\
\text { wynikające działalności organizacji, } \\
\text { - pierwszeństwo - szybkość reakcji organizacji na roszczenia i ocze- } \\
\text { kiwania interesariusza, wynikająca z wrażliwości i stopnia krytycz- } \\
\text { ności wzajemnych relacji }\end{array}$ \\
\hline
\end{tabular}

Źródło: [Ciechan-Kujawa 2014, s. 56-57]. 
Można przyjąć, że im więcej atrybutów posiada interesariusz, tym jego wpływ na jednostkę jest większy, jednak należy mieć na względzie, że rola poszczególnych interesariuszy i ich znaczenie zmieniają się [Paliwoda-Matiolańska 2009, s. 58]. Motywy współpracy oraz wzajemne oczekiwania stron również ulegają zmianie wraz z rozwojem danej relacji. Skrzypek [2015, s. 158] słusznie zauważa, że każdą relację charakteryzuje unikalna dynamika rozwoju i unikalne oczekiwania.

Określając znaczenie interesariuszy, należy ocenić, czy przedsiębiorstwo może realizować swoją strategię bez udziału danego interesariusza. W szczególności należy uwzględnić trzy kryteria: (1) istotność dostarczanych przez interesariuszy zasobów dla odniesienia sukcesu biznesowego, (2) zaangażowanie wiążące się z ryzykiem utraty lub wzrostu wartości (np. kapitału, kariery, dobrobytu) w zależności od stopnia powodzenia przedsięwzięcia, (3) poziom władzy zapewniający możliwość korzystnego lub niekorzystnego wpływu na wyniki działań organizacji [Kochan, Rubenstein 2000, s. 373].

Poziom wpływu interesariuszy na działalność jednostki można oceniać w kategoriach oddziaływania na generatory wartości, wśród których w literaturze najczęściej wymienia się zdefiniowane przez Rappaporta [1999, s. 78-79]: tempo wzrostu przychodów ze sprzedaży, marżę na działalności operacyjnej, efektywną stopę podatkową, inwestycje w aktywa obrotowe netto, inwestycje w aktywa trwałe, koszt kapitału, okres trwania przewagi konkurencyjnej. Inni autorzy [Foley i in. 2007, s. 19-20; Ciechan-Kujawa 2014, s. 52-55] podnoszą konieczność szerszego ujęcia omawianej problematyki z perspektywy tworzenia wartości dla wszystkich interesariuszy i wśród kluczowych generatorów wskazują: uczciwość i przejrzystość finansową, minimalizację ryzyka działalności, jakość usług i produktów, zysk/wartość dla udziałowców/akcjonariuszy, innowacje, wiedzę, zdrowie i bezpieczeństwo, wpływ na środowisko, etykę, integrację/bezpieczeństwo danych, skuteczne zarządzanie oparte na PDCA, reputację, zarządzanie łańcuchem dostaw, relacje społeczne, przywództwo i kompetencje w zarządzaniu.

\section{Relacje jako rodzaj aktywów niematerialnych przedsiębiorstwa}

Interesariusze mogą w znaczący sposób oddziaływać na realizację celów przedsiębiorstw, a nawet trwale przyczynić się do ich sukcesu finansowego. Umowne i pozaumowne powiązania i relacje $\mathrm{z}$ interesariuszami można zatem rozpatrywać jako rodzaj zasobu strategicznego, posiadającego wartość, który efektywnie wykorzystywany, może doprowadzić do uzyskania istotnej przewagi konkurencyjnej przedsiębiorstwa.

Relacje z interesariuszami są określane mianem kapitału relacyjnego, stanowiącego element kapitału intelektualnego [Roos, Roos 1998]. W literaturze przedmiotu wartość kapitału intelektualnego określana jest różnicą między wartością rynkową 
a księgową przedsiębiorstwa, wynikającą z wartości kapitału ludzkiego i strukturalnego, w tym relacyjnego ${ }^{1}$, zgromadzonego przez jednostkę [Herman 2008, s. 39; Wróbel 2009, s. 11-15; Kasiewicz i in. 2006, s. 87]. M. Marcinkowska [2011, s. 496] uważa jednak, iż takie podejście do określenia jego wartości jest niepoprawne.

Ujwary-Gil [2009, s. 15] zauważa, że zasoby materialne, jak i niematerialne mają za zadanie współistnieć ze sobą i wyłącznie ich współdziałanie może tworzyć wartość przedsiębiorstwa na rynku. Wycena przedsiębiorstwa powinna zatem obejmować zarówno czynniki materialne, jak i niematerialne, takie jak na przykład: kultura organizacyjna, know-how, reputacja organizacji, trwałość relacji z interesariuszami, kompetencje pracowników, innowacyjność działalności. Należy jednak podkreślić, że w procesie budowania przewagi konkurencyjnej znaczenie mają zasoby cenne i rzadkie, ale przede wszystkim trudne do imitacji, a sieć relacji zewnętrznych i wewnętrznych podmiotu ma właśnie takie cechy. Niepowtarzalna architektura wewnętrzna tworzona jest przez interesariuszy stanowiących przedsiębiorstwo, kreujących atmosferę oraz zaufanie wewnątrz niego. Architektura zewnętrzna obejmuje zbiór relacji z subkontraktowymi i instytucjonalnymi interesariuszami otoczenia i ma swoje odzwierciedlenie między innymi w: sieci sprzedaży, projektach badawczo-rozwojowych, bazie klientów, partnerstwie strategicznym [Wilk 2004, s. 231].

Opisana powyżej architektura pozwala przedsiębiorstwom na elastyczne reagowanie na zmianę okoliczności oraz zapewnia sprawny przepływ informacji. Kay [1996, s. 32] twierdzi, że przewaga konkurencyjna uzyskana w następstwie kapitału relacyjnego jest bardziej trwała, co wynika z faktu, że skopiowanie innych niematerialnych źródeł przewagi konkurencyjnej (np. rozwiązań innowacyjnych) nie stanowi już tak dużego problemu jak np. odzwierciedlenie relacji z klientami. Przedmiot zainteresowania badaczy powinny stanowić zatem narzędzia, formy i metody kreowania kapitału relacyjnego przedsiębiorstwa w kontekście wzmacniania ich konkurencyjności, ale również metody wyceny tych relacji. Z punktu widzenia przedsiębiorstwa zaspokojenie wszystkich potrzeb nie zawsze jest możliwe i zasadne. Zarządzanie relacjami z interesariuszami jako istotnym zasobem strategicznym powinno przede wszystkim skutecznie oddziaływać na dynamikę przyrostu wartości przedsiębiorstwa - podkreśla Jabłoński [2011, s. 204-205]. Takie założenie zdaniem autorów wymaga zbudowania modelu wyceny relacji z interesariuszami, a następnie efektywnego zarządzania cyklem życia interesariuszy z uwzględnieniem rentowności relacji oraz wyceny, z jednej strony, wkładu interesariuszy w procesy kreowania wartości przedsiębiorstwa, z drugiej - systemu zachęt wobec nich.

1 Kapitał relacyjny wskazywany jest jako część kapitału strukturalnego lub jako wyodrębniony rodzaj kapitału. Przeglądu różnych klasyfikacji kapitału dokonała między innymi A. Ujwary-Gil [2009, s. 37]. 


\section{Wycena relacji z interesariuszami w ramach kapitału intelektualnego}

Wycena relacji z interesariuszami jest wyzwaniem z punktu widzenia zarówno analityków finansowych, inwestorów giełdowych, jak i samych zarządzających przedsiębiorstwem tworzącym relacje. Jej zasadniczym celem jest ustalenie kwoty przyszłych korzyści ekonomicznych (np. dodatkowych przychodów, zysków lub przepływów pieniężnych), bądź oszczędności (np. kosztowych lub wydatkowych) wynikających z istnienia i rozwoju relacji z interesariuszami. Motywacją skłaniającą do wyceny relacji jest niewątpliwie chęć bardziej efektywnego zarządzania relacjami z różnymi grupami interesu, wybór relacji, które powinny być kontynuowane, czy wreszcie uzasadnienie ponoszenia nakładów na tworzenie, podtrzymanie czy rozwój relacji z określonymi interesariuszami. Dzięki wycenie relacji możliwe jest określenie obszarów działalności przedsiębiorstwa, które powinny zostać zmienione celem uzyskania wzrostu jego wartości.

Jednym z kluczowych uwarunkowań determinujących proces wyceny relacji jest niewątpliwie ich niematerialny charakter, który istotnie zawęża wykorzystanie metod ustalenia ich wartości, a także zróżnicowanie grup tworzących relacje zarówno w ramach samego przedsiębiorstwa, jak i w jego otoczeniu bliższym i dalszym. Zgodnie z ustawą o rachunkowości relacje wewnętrzne bądź zewnętrzne przedsiębiorstwa nie podlegają ewidencji bilansowej, a tym samym nie są traktowane jako aktywa zaliczane do wartości niematerialnych i prawnych ${ }^{2}$. Relacje ujęte łącznie w postaci kapitału intelektualnego podlegają ujęciu bilansowemu tylko w przypadku przejęcia/dołączenia jednostki po cenie wyższej niż jej księgowa/godziwa wartość netto [Śledzik 2011]. Podejście takie pozwala na ujęcie wszystkich relacji w kategorii określonej jako wartość firmy (goodwill) wraz z innymi zasobami niematerialnymi. Nie pozwala ona jednak kalkulować wartości relacji z poszczególnymi grupami interesariuszy.

W odniesieniu do kapitału intelektualnego zarówno w teorii, jak i praktyce zostało zidentyfikowanych oraz opisanych wiele metod jego wyceny. Strojny [2003, s. 105-106] wskazuje na cztery zasadnicze grupy metod wyceny kapitału intelektualnego obejmujące: metody oparte na kapitalizacji giełdowej (wskaźnik Q Tobina, wskaźnik MV/BV), metody oparte na wskaźnikach rentowności (EVA, CIV, KCE, VAIC, HRCA), metody oparte na bezpośrednim pomiarze kapitału intelektualnego (IAV, TVC, IVM), metody oparte na kartach punktowych (BSC, Skandia Navigator, IC-Rating, IAM). Wymienione metody, chociaż pozwalają na ustalenie całościowe lub częściowe wartości kapitału intelektualnego, nie mogą być bezpośrednio zastosowane do ustalenia wartości poszczególnych relacji z różnymi grupami interesariuszy.

2 Ustawa z dnia 29 września 1994 r. o rachunkowości, Dz.U. z 1994, nr 121, poz. 591, wskazuje na powstanie wartości niematerialnych i prawnych poprzez nabycie bądź poprzez poniesienie kosztów zakończonych prac rozwojowych. Relacje nie mogą być również ujęte jako inwestycje, które co do zasady nie są użytkowane przez jednostkę, ale posiadane celem osiągnięcia korzyści finansowych. 


\section{Wycena relacji z poszczególnymi grupami interesariuszy}

Relacje z poszczególnymi grupami interesariuszy są integralnymi składowymi wartości przedsiębiorstwa i podlegają wycenie. Problemem w procesie ustalenia ich wartości jest niewątpliwie zróżnicowany charakter poszczególnych grup interesu, zmienność relacji w czasie (występowanie ich cyklu życia), a także możliwy brak bezpośrednich korzyści ekonomicznych osiąganych wprost z tytułu współpracy $\mathrm{z}$ wybranymi interesariuszami (zwłaszcza z otoczenia dalszego).

Wśród interesariuszy na szczególną uwagę zasługują klienci i relacje z nimi, ponieważ ich wpływ na działalność przedsiębiorstwa jest większy niż w przypadku innych grup interesu, a korzyści ekonomiczne z nimi związane są stosunkowo najłatwiej kwantyfikowalne [Dąbrowski 2013, s. 199-201]. W ich przypadku dostępnych jest wiele wskaźników pomiaru wartości, w tym: RFM, SOW, PCV, CLV [Dobiegała-Korona, Doligalski (red.) 2010]. Niemniej w praktyce funkcjonowania przedsiębiorstw nie można pominąć innych grup interesariuszy (zwłaszcza zewnętrznych), których interakcja z przedsiębiorstwem będzie determinowała jego rozwój i tworzenie wartości rynkowej (np. dostawców, inwestorów, organizacje pozarządowe, społeczność lokalną, władze samorządowe). W ich przypadku wycena będzie zdecydowanie trudniejsza, ponieważ relacje nie będą przekładały się wprost na bieżące korzyści ekonomiczne jednostki, a ich wpływ na korzyści przedsiębiorstwa będzie jedynie pośredni i oddalony istotnie w czasie.

Wycena relacji z poszczególnymi interesariuszami może być przeprowadzona zasadniczo na podstawie trzech podejść znanych z wyceny całego przedsiębiorstwa: kosztowego, dochodowego oraz rynkowego. Specyfika oraz niepowtarzalność relacji będzie właściwie uniemożliwiała zastosowanie tego ostatniego. Z racji ścisłego zindywidualizowania, relacje jednostki nie będą mogły być przedmiotem porównania rynkowego ani wyceny na rynku kapitałowym. W przypadku zastosowania podejścia dochodowego przedsiębiorstwo będzie musiało zidentyfikować przyszłe korzyści ekonomiczne relacji w postaci zysków lub przepływów pieniężnych oraz stopę dyskontową odzwierciedlającą ryzyko możliwości niepodjęcia, zmiany lub zakończenia relacji. Relatywnie najprostsze do zastosowania w wycenie relacji będzie podejście kosztowe, jednakże będzie ono przydatne przede wszystkim do ustalenia wartości relacji z interesariuszami wewnętrznymi. Do wyceny relacji nie będzie można zastosować wprost metodyki wyceny stosowanej dla ustalenia wartości całego przedsiębiorstwa. W szczególności nie będą miały tu zastosowania metody oparte na wartości księgowej z racji braku możliwości uznania relacji za aktywa bilansowe. 


\section{Podsumowanie}

Przemiany społeczno-gospodarcze obserwowane współcześnie potwierdzają wzrost znaczenia zasobów niematerialnych w działalności zarówno podmiotów gospodarczych, jak i instytucji non profit. Zasoby (aktywa) niematerialne, które są unikatowe, niepowtarzalne i charakteryzują konkretny podmiot, stają się determinantami osiągania przewag konkurencyjnych oraz tworzenia wartości przedsiębiorstwa, wypierając przy tym aktywa materialne. Jednym z kluczowych obszarów wartości niematerialnych stają się relacje z różnymi grupami interesariuszy. Pomiar i wycena relacji stają się o tyle istotne, iż w ramach podmiotu gospodarczego występuje zwykle interakcja wielu różnych relacji, które w połączeniu z zasobami rzeczowymi składają się na całkowitą wartość dla właścicieli. Poznanie problematyki wyceny relacji pozwala na zoptymalizowanie działań zarządczych w przedsiębiorstwie, a w efekcie na maksymalizowanie wartości przedsiębiorstwa. Badania prowadzone w ramach niniejszej pracy stanowią przyczynek do dalszej dyskusji oraz oceny możliwości wykorzystania różnych metod wyceny do ustalenia wartości poszczególnych relacji.

\section{Literatura}

Adamik A., 2009, Cooperative partnership as a tool for optimizing efficiency of enterprises, [w:] Integration of Supply Chain - Modeling, Partnership and Management, eds. K. Grzybowska, A. Stachowiak, Monograph, Publishing House of Poznan University of Technology, Poznań.

Andriof J., Waddock S., 2002, Unfolding stakeholder engagement, [w:] Unfolding Stakeholder Thinking: Theory, Responsibility and Engagement, eds. J. Andriof, S. Waddock, B. Husted, S. Sutherland Rahman, Greenleaf Publishing, vol. 1.

Bhimani A., Soonawalla K., 2005, From conformance to performance: The corporate responsibilities continuum, Journal of Accounting and Public Policy, vol. 24, issue 3.

Ciechan-Kujawa M., 2014, Wielowymiarowy audyt biznesowy. Wartość dodana dla organizacji i interesariuszy, Wydawnictwo UMK, Toruń.

Czakon W., 2008, Koordynacja sieci - wieloraka forma organizacji wspótdziatania, Przegląd Organizacji, $\mathrm{nr} 9$.

Dąbrowski T., 2013, Dylematy wyceny wartości relacji z interesariuszami, Studia Prawno-Ekonomiczne, t. LXXXIX.

Dobiegała-Korona B., Doligalski T. (red.), 2010, Zarządzanie wartościa klienta. Pomiar i strategie, Poltext, Warszawa.

Dundee T.W., 2008, Stakeholder theory. Managing corporate social responsibility in a multiple actor context, [w:] Corporate Social Responsibility, eds. A. Crane et al., Oxford University Press, New York.

Esty D.C., Winston A.S., 2007, Green to gold, Yale University Press, New Heaven.

Foley K.J., Hensler D.A., Jonker J., 2007, Quality matters, [w:] Quality Management and Organizational Excellence: Oxymorons, Empty Boxes or Significant Contributions to Management Thought and Practice?, eds. K.J. Foley, D. Hensler, J. Jonker, SAI Global Limited, Sydney.

Freeman R.E., 1984, Strategic Management: A Stakeholder Approach, Pitman, Boston. 
Freeman R.E., Harisson J.S., Wics A.C., 2007, Managing for Stakeholders. Survival, Reputation and Success, Yale University Press.

Freeman R.E., Reed D.L., 1983, Stockholders and stakeholders: A new perspective on corporate governance, California Management Review, vol. 25, issue 3, s. 88-106.

Hawkins D.E., 2006, Corporate Social Responsibility. Balancing Tomorrow's Sustainability and Today's Profitability, Palgrave, New York.

Herman A., 2008, Kapitat intelektualny i jego liczenie, Kwartalnik Nauk o Przedsiębiorstwie, nr 3.

Jabłoński A., 2011, Zasobowy aspekt teorii interesariuszy w modelu zrównoważonego biznesu, [w:] Rozwój szkoły zasobowej zarządzania strategicznego, red. R. Krupski, Wyd. WSZiP, Wałbrzych.

Johnson G., Scholes K., 1999, Exploring Corporate Strategy. Text and Cases, Prentice Hall, London.

Kasiewicz S., Rogowski W., Kicińska M., 2006, Kapitat intelektualny. Spojrzenie z perspektywy interesariuszy, Oficyna Wydawnicza, Kraków.

Kay J., 1996, Podstawy sukcesu firmy, PWE, Warszawa.

Kochan T., Rubenstein S., 2000, Toward a stakeholder theory of the firm: The saturn partnership, Organizational Science, no. 11(4).

Laszlo Ch., 2008, Firma zrównoważonego rozwoju, Studio EMKA, Warszawa.

Lawrence A.T., Weber J., 2008, Business \& Society, Stakeholders, Ethics, Public Policy, McGraw-Hill, New York.

Lechner Ch., Dowling M., Welpe I., 2006, Firm networks and firms development: The role of the relational mix, Journal of Business Venturing, vol. 21, issue 4.

Marcinkowska M., 2011, Wycena zasobów niematerialnych, [w:] Wycena przedsiębiorstwa, red. M. Panfil, A. Szablewski, Poltext, Warszawa.

Mitchell R.K. i in., 1997, Toward a theory of stakeholder. Identification and salience: Defining the principle of who and what really counts, Academy of Management Review, vol. 22, no. 4.

Morsing M., 2006, Corporate Social Responsibility communication: stakeholder information, response and involvement strategies, Business Ethics: A European Review, vol. 15, no. 4.

Niedzielski P., 2005, Polityka innowacyjna w transporcie - wybrane zagadnienia, Przegląd Komunikacyjny, $\mathrm{nr}$ 7-8.

Obłój K., 2014, Strategia organizacji, PWE, Warszawa.

Paliwoda-Matiolańska A., 2009, Odpowiedzialność społeczna w procesie zarzadzania przedsiębiorstwem, C.H. Beck, Warszawa.

Rappaport A., 1999, Wartość dla akcjonariuszy. Poradnik menedżera i inwestora, WIG-Press, Warszawa.

Romanowska M., 2004, Leksykon zarządzania, Difin, Warszawa.

Roos G., Roos, J., 1998, Intellectual Capital, New York University Press, New York.

Skalik J., 2006, Problem dynamiki zmian w zarządzaniu wspótczesnymi organizacjami, [w:] Zmiana warunkiem sukcesu. Dynamika zmian w organizacji - ewolucja czy rewolucja, red. J. Skalik, Wydawnictwo AE we Wrocławiu, Wrocław.

Skrzypek E., 2015, Wpływ zaufania i relacji na rozwój kapitału społecznego organizacji, [w:] Funkcjonowanie i doskonalenie zarzadzania. Aspekty społeczne, red. U. Balon, T. Sikora, Kraków.

Strojny M., 2003, Metody i narzędzia pomiaru kapitału intelektualnego w organizacji, [w:] Pomiar i rozwój kapitatu ludzkiego przedsiębiorstwa, red. D. Dobija, PFPK, Warszawa.

Śledzik K., 2011, Kapitat intelektualny a wartość rynkowa banków giełdowych, Fundacja Rozwoju Uniwersytetu Gdańskiego, Gdańsk.

Ujwary-Gil A., 2009, Kapitat intelektualny a wartość rynkowa przedsiębiorstwa, C.H. Beck, Warszawa.

Wilk J., 2004, Symulacyjny model kapitału intelektualnego przedsiębiorstwa, Prace Naukowe Instytutu Organizacji i Zarządzania, nr 75, Politechnika Wrocławska, Wrocław.

Wit B. De, Meyer R., 2007, Synteza strategii. Tworzenie przewagi konkurencyjnej przez analizowanie paradoksów, PWE, Warszawa.

Wróbel J., 2009, Geneza rozwoju kapitału intelektualnego i jego struktura, [w:] Kapitat relacyjny w nowoczesnej gospodarce, red. M. Cisek, Studio Emka, Warszawa. 